\title{
On the regional background levels of carbon monoxide observed in East Asia during 1991 2004
}

\author{
H. S. Kim • P. P. Tans • P. C. Novelli
}

Received: 1 May 2007 / Accepted: 13 December 2007 / Published online: 20 March 2008

(C) Springer Science + Business Media B.V. 2008

\begin{abstract}
The carbon monoxide (CO) concentrations observed in Mt. Waliguan in China (WLG), Ulaan Uul in Mongolia (UUM), Tae-ahn Peninsula in Korea (TAP) and Ryori in Japan (RYO) were analysed between 1991 and 2004. The average annual concentration of $\mathrm{CO}$, a toxic air pollutant, was the highest at TAP $(233 \pm 41 \mathrm{ppb})$, followed by RYO (171 $\pm 36 \mathrm{ppb})$, UUM (155 $\pm 26 \mathrm{ppb})$ and WLG $(135 \pm 22 \mathrm{ppb})$. CO tends to be highest in spring and lowest in summer in East Asia, with the exception of WLG. TAP had the highest $\mathrm{CO}$ concentrations in all seasons compared with WLG, UUM and RYO and displays a wide short-term variability in concentration. This is caused by large-scale air pollution owing to its downwind location, close to continental East Asia. CO concentrations observed at TAP were analysed as follows: according to the origin of the isentropic backward trajectory and its transport passage, as continental background airflows (CBG) measuring 216 $47 \mathrm{ppb}$, regionally polluted continental airflows (RPC) measuring $316 \pm 56 \mathrm{ppb}$, oceanic background airflows (OBG) measuring $108 \pm 41 \mathrm{ppb}$ and partly perturbed oceanic airflows measuring $161 \pm 6 \mathrm{ppb}$. The high concentrations of $\mathrm{CO}$ at TAP are because of the airflow originating from the East Asian continent, rather than the North Pacific. RPCs, which pass through eastern China, appear to have high $\mathrm{CO}$ concentrations in spring, autumn and winter. OBGs, however, are affected by North Pacific air masses
\end{abstract}

H. S. Kim $(\bowtie)$

Korea Centre for Atmospheric Environment Research, Cheongwon, Choongbook 363-891, Korea

e-mail: envir007@chol.com

P. P. Tans $\cdot$ P. C. Novelli

NOAA/Earth System Research Laboratory,

Global Monitoring Division,

Boulder, CO 80305, USA with low CO concentrations in summer. National Oceanic and Atmospheric Administration satellite images and the Goddard Earth Observing System (GEOS)-Chem simulation model confirmed that a large-scale air pollution event originated in eastern China and reached the Korean Peninsula and the Korea East Sea by way of the Yellow Sea. It is noteworthy that the overall trend at TAP does not show an increase despite the fact that energy use in China approximately doubled from 1991 to 2004 .

Keywords Carbon monoxide - Regional background level · Large-scale air pollution · Transport passage $\cdot$ Satellite image

\section{Introduction}

The East Asian region, which includes China, Korea and Japan, is one of the world's three top manufacturing regions and has experienced consistent annual increases in anthropogenic emissions (Streets et al. 2001). Total emissions of $\mathrm{CO}$ for the Asian region in 2000 were estimated as $279 \mathrm{Tg}$, of which $116 \mathrm{Tg}$ was from China, accounting for $42 \%$ of emissions (Streets et al. 2003). Although $90-95 \%$ of CO emissions are removed through their reaction with $\mathrm{OH}$ in the atmosphere (Logan et al. 1981), toxic CO is widely distributed in the East Asian region by long-range transport, owing to the large quantity of emissions and their severalmonths lifetime, depending on the season (Novelli et al. 1998).

Air pollutants emitted on a large-scale from the East Asian continent, particularly from China, are recognised to affect Korea, some originating from a distance of several hundred or even thousands of kilometres (Chung et al. 2001, 2003; Kim and Chung 2005). Emissions in East Asia also affect ground measurements of $\mathrm{CO}$ in regions such as 
Japan, the North Pacific and the west coast of North America (Akimoto et al. 1996; Jaffe et al. 1997; Liang et al. 2004; Pochanart et al. 2004). Intensive observation campaigns have therefore been conducted to identify the atmospheric chemical components in the East Asian region and the characteristics of their movements (Hoell et al. 1996, 1997; Huebert et al. 2003; Jacob et al. 2003).

Long-term observation of background sites yields valuable information regarding changes in atmospheric components caused by long-range transport. Background concentrations of $\mathrm{CO}$ have remained approximately constant in time, with systematically higher concentrations in the Northern Hemisphere compared with the Southern Hemisphere, displaying the highest concentrations in the high latitudes of the Northern Hemisphere between late winter and early spring (Novelli et al. 1998). This study, however, focuses on the regional background concentration of $\mathrm{CO}$ based on long-term observations in East Asia, which is mainly affected by westerly winds high in $\mathrm{CO}$ emissions. In general, $\mathrm{CO}$ measurements at TAP were made when the fresh air arrived, e.g., with the arrival of a new anticyclone. Thus, high CO values greater than $300 \mathrm{ppb}$ were not included in this study. Regional background concentrations of CO at Tae-ahn on the Korean Peninsula, adjacent to the East Asian continent, were measured in the early 1990s (Chung and Lee 1993). The characteristics of regional background concentrations of CO collected from 1991 to 2004, according to the transport passage of the airflows in the East Asian region, are analysed in this study.

\section{Data and analysis methods}

Figure 1 shows the geographic locations of the measurement sites in the East Asian region. The National Oceanic

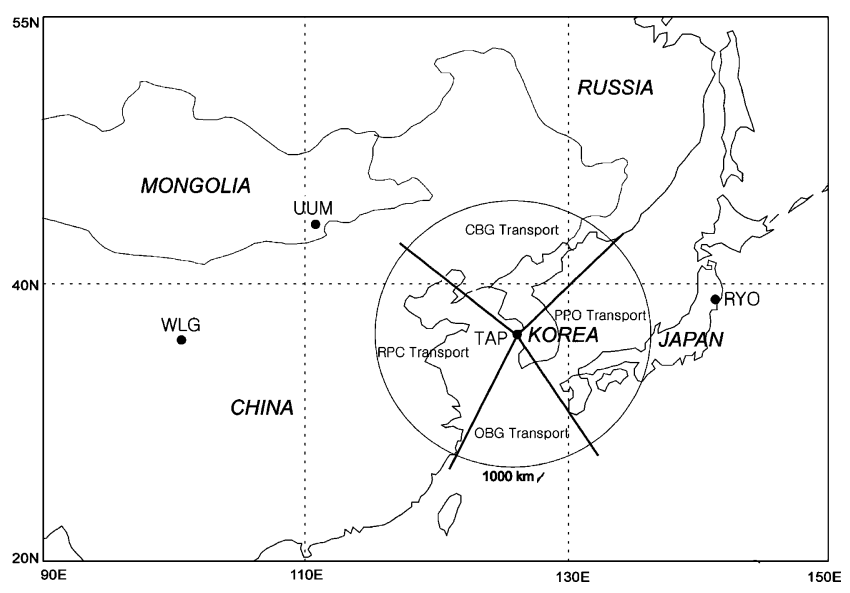

Fig. 1 Locations of the background sites in the East Asian region. Passages of the movement of the airflows arriving at TAP are classified as $\mathrm{CBG}$ transport, RPC transport, OBG transport and PPO transport
Table 1 Details of the background sites in the East Asian region

\begin{tabular}{lllll}
\hline Station Name & Country & Latitude & Longitude & $\begin{array}{l}\text { Altitude } \\
\text { (a. s. 1) }\end{array}$ \\
\hline WLG & China & $36^{\circ} 17^{\prime} \mathrm{N}$ & $100^{\circ} 54^{\prime} \mathrm{E}$ & $3,810 \mathrm{~m}$ \\
UUM & Mongolia & $44^{\circ} 27^{\prime} \mathrm{N}$ & $111^{\circ} 05^{\prime} \mathrm{E}$ & $914 \mathrm{~m}$ \\
TAP & Korea & $36^{\circ} 43^{\prime} \mathrm{N}$ & $126^{\circ} 07^{\prime} \mathrm{E}$ & $20 \mathrm{~m}$ \\
RYO & Japan & $39^{\circ} 02^{\prime} \mathrm{N}$ & $141^{\circ} 49^{\prime} \mathrm{E}$ & $260 \mathrm{~m}$ \\
\hline
\end{tabular}

and Atmospheric Administration Earth System Research Laboratory (NOAA/ESRL) Carbon Cycle Greenhouse Gases Group in the USA has a globally distributed airsampling network in the East Asian region, which includes TAP in Korea, UUM in Mongolia and WLG in China. The Japan Meteorological Agency operates the RYO observatory. Further details pertaining to each observation site are summarised in Table 1. TAP and RYO, as opposed to WLG and UUM, are located on the downwind side of the East Asian continent, and TAP is most affected by anthropogenic air-pollutant emissions, which arrive by long-range transport from China (Chung et al. 2001; Kim and Chung 2005). Air for measuring CO concentrations was collected by equipment provided by the NOAA/ESRL, which pumped air into two (duplicate) glass flasks. Measurement was conducted once or twice each week at 12-16 Local Standard Time (LST), beginning in 1990. The collected air samples were sent to the NOAA/ESRL in the USA to obtain accurate concentrations of $\mathrm{CO} . \mathrm{CO}_{2}$ and $\mathrm{CH}_{4}$ concentrations were also analysed, and the regional background concentrations of these gas components observed at TAP were studied (Chung and Lee 1992; Lee and Chung 1993). A detailed analysis of the collected air is described in Novelli et al. (1998), using the CO concentration data from TAP, WLG and UUM, analysed by the NOAA/ESRL for 1991 to 2004. CO concentrations at RYO are based on data from the Japan Meteorology Agency. In this study, CO data measured at Mauna Loa (MLO) in Hawaii by NOAA/ESRL are also compared with the data from four Asian stations.

To estimate the regional background $\mathrm{CO}$ concentration along the airflow transport passages in the East Asian region, $\mathrm{CO}$ concentrations and isentropic backward trajectories measured at TAP between 1991 and 2004 were analysed. The Hybrid Single-Particle Lagrangian Integrated Trajectory model (Draxler and Rolph 2003) was used to track the path of airflows in the East Asia region. The trajectories arrived at 09 LST on each day when the air was collected at TAP.

The isentropic backward trajectories arriving at TAP, originating approximately $1,000 \mathrm{~km}$ away, are divided into four groups according to their origin and transport routes 
(Fig. 1). The trajectory passages that circulate during transport are excluded from the analysis. Observed $\mathrm{CO}$ data in the East Asian region demonstrate clear seasonal changes owing to the influences of Siberian continental air masses affected by the monsoon and oceanic air masses from the North Pacific. Isentropic backward trajectories are accordingly divided into continental- and oceanic-originating airflows.

The trajectories of air masses of continental origin are divided into two groups depending on the distribution of $\mathrm{CO}$ emission in the East Asian region (Liang et al. 2004) and the transport passage before it reaches TAP. The isentropic backward trajectory of continental origin is classified as follows: continental background (CBG) transports originating in northeast China and the eastern Siberian region. Both pass through the NW NNE portion of the Korean peninsula, and regionally polluted continental (RPC) transports, originating from the Chinese continent and landmasses at lower latitudes, pass through the eastern area, then move south to Bohai Bay in China and the Yellow Sea before arriving at TAP. CBGs do not pass through the area where there are high industrial $\mathrm{CO}$ emission rates. RPCs pass through the industrial district in the eastern region of China. This region also includes the densely populated urban areas of Beijing, Tianjin and Shanghai.

Kim and Chung (2005) classify the ozone concentrations measured at TAP into CBG concentrations and the level of regionally polluted airflows, according to the isentropic backward trajectories. Continental airflows appear mainly in spring, autumn and winter. Trajectories of oceanic origin are classified by oceanic background (OBG) transports originating in the western North Pacific, arriving at TAP by way of the East China Sea and the Yellow Sea, and partly perturbed oceanic (PPO) transports passing through Japan and Korea.

\section{Results and discussion}

\section{$\mathrm{CO}$ distribution in East Asia}

Figure 2 shows the annual average variations in $\mathrm{CO}$ concentration measured at WLG in China, UUM in Mongolia, TAP in Korea, RYO in Japan and MLO in Hawaii between 1990 and 2004. Compared with CO data of MLO in Hawaii $\left(19.54^{\circ} \mathrm{N}, 155.58^{\circ} \mathrm{W}, 3,397 \mathrm{~m}\right)$, with $96 \pm 19 \mathrm{ppb}$ of $\mathrm{CO}$, the East Asian region shows high concentrations of $135 \pm 22 \mathrm{ppb}$ at WLG, $155 \pm 26 \mathrm{ppb}$ at UUM, $171 \pm 36 \mathrm{ppb}$ at RYO, and $233 \pm 41 \mathrm{ppb}$ at TAP. Although TAP and WLG are in close latitudinal proximity, WLG is at high altitude and upwind of the East Asian industrial region. TAP appears to display the highest carbon monoxide concentrations, being located 350-700 km downwind of the eastern part of China. UUM, located upwind of where the continental pollution originates, demonstrates lower carbon monoxide concentrations than at TAP but higher concentrations than at WLG. It should be noted that annual mean $\mathrm{CO}$ at TAP appears to be trending down slightly over these last 14 years, despite the rapid industrialisation of China.

RYO in Japan, in an easterly direction from the East Asian continent further downwind than TAP, displays lower concentrations than those at TAP. In terms of annual mean variations, UUM, TAP, RYO and MLO were observed in 1998 to have high CO concentrations. The annual mean of ozone concentrations was also high at Chongwon, an agricultural area in central South Korea (Kim and Chung 2003). More forest fires in Siberia occurred in 1998 than in any other year on record, and Kato et al. (2002) suggest that $\mathrm{CO}$ concentrations and the ozone concentrations measured at Happo, Japan in 1998 had increased by $\sim 30$ and $\sim 7 \mathrm{ppb,}$ respectively, as a result of the long-range transport caused by the forest fires in Siberia. At that time, the CBG trajectories stayed at low altitudes moving to the east.
Fig. 2 Annual mean $\mathrm{CO}$ concentrations at Mt. Waliguan $(W L G)$ in China, Ulaan Uul in Mongolia (UUM), Tae-ahn Peninsula $(T A P)$ in Korea, Ryori $(R Y O)$ in Japan, and Mauna Loa $(M L O)$ in Hawaii for 1990 2004

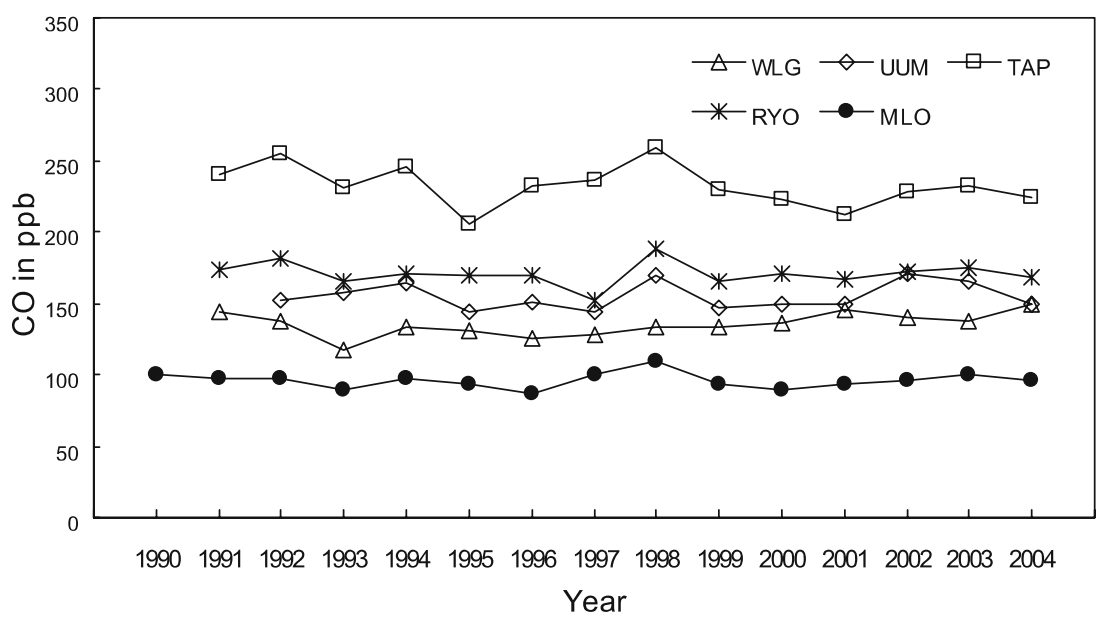


Figure 3 shows histograms of the $\mathrm{CO}$ concentrations measured at TAP, UUM and WLG between 1991 and 2004. These three measurement sites display important differences. The limited range of the histogram in the
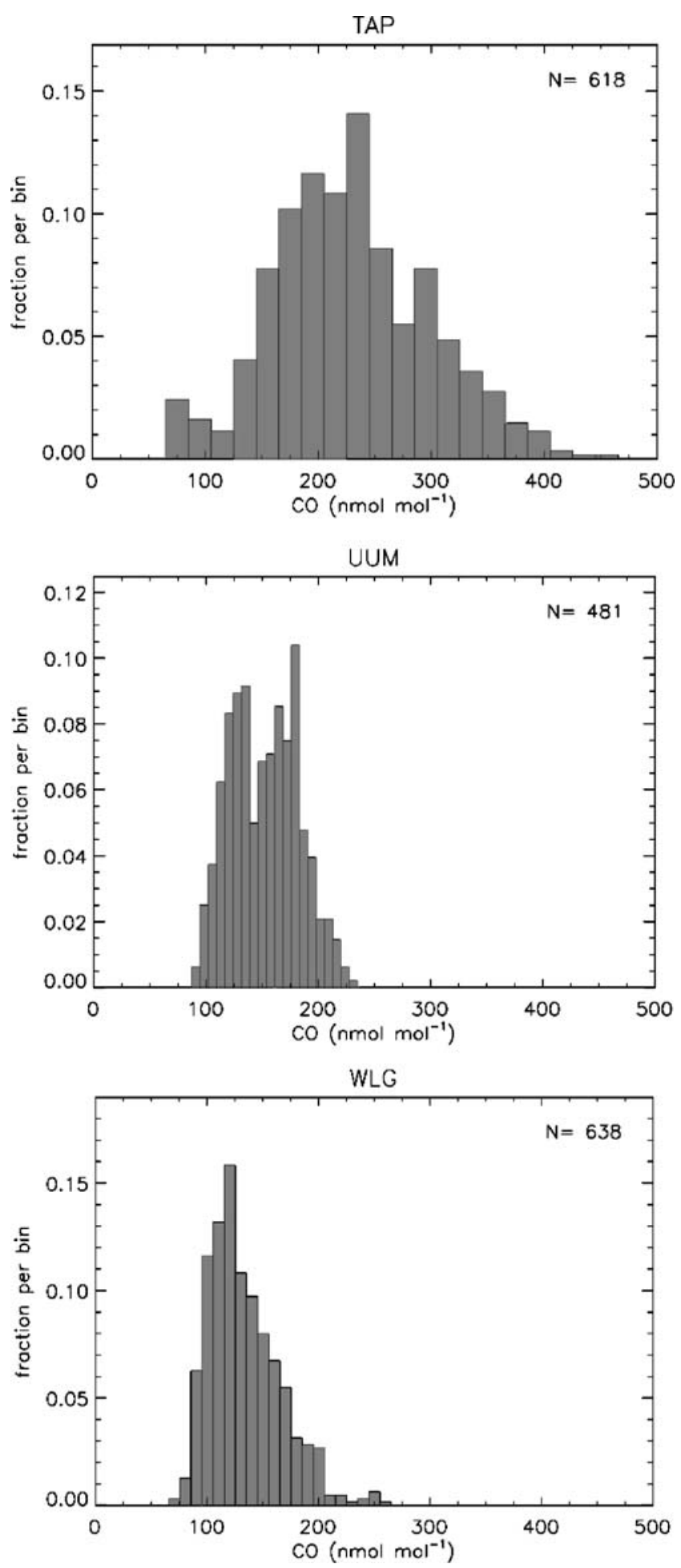

Fig. 3 Histograms of CO concentrations measured at TAP, UUM, and WLG for 1990 2004 graph for WLG explains the consistently similar CO concentrations. CO data at TAP demonstrate, however, a wide range of distribution because $\mathrm{CO}$ is affected by large-scale transport of air pollution (LSTAP). The distribution of $\mathrm{CO}$ concentrations at UUM falls between those for WLG and TAP. The bump at low CO concentrations is notable for TAP but not for the other sites, which confirms the occurrences of transport from the OBG sector.

Seasonal variation of $\mathrm{CO}$ concentrations in East Asia

Figure 4 shows the monthly average variations in $\mathrm{CO}$ concentration observed at WLG, UUM, TAP, RYO and MLO between 1990 and 2004. Generally, CO concentrations are highest between March and May and lowest in July and August (November at WLG), and gradually increase in autumn and winter. The $\mathrm{CO}$ characteristics of the East Asian region reflect the emissions and their longrange transport, influenced by continental and oceanic air masses, with similar results to observations made at various sites in Japan (Pochanart et al. 1999, 2004). CO from fossil fuel combustion accumulates in the atmosphere in winter and early spring, increasing $\mathrm{CO}$ concentrations. In summer, however, the region is influenced by maritime airflows originating in the Pacific Ocean. These maritime air masses generally have low $\mathrm{CO}$ concentrations.

The differences between the highest and the lowest monthly mean $\mathrm{CO}$ concentrations were $85 \mathrm{ppb}$ at TAP and $92 \mathrm{ppb}$ at RYO, suggesting significant seasonal variations. The variation is larger at RYO than at TAP because the area is under the influence of North Pacific air masses during summer. WLG, however, displays a minimum of about $110 \mathrm{ppb}$ in November, after a maximum of about $158 \mathrm{ppb}$ in March. Seasonal variations at WLG compare to measurements at TAP. Both observation stations are located at similar latitudes. WLG measurements displayed a small variation compared with the other regions because it is located upwind of East Asia and is less influenced by the atmospheric boundary layer, located at an altitude of $3,810 \mathrm{~m}$. The difference between the highest and the lowest monthly average concentrations of $\mathrm{CO}$ at UUM was $54 \mathrm{ppb}$, which falls between the measurements obtained at WLG and TAP.

Figure 5 depicts the seasonal histogram of $\mathrm{CO}$ concentrations measured at TAP, UUM and WLG between 1991 and 2004. Spring in this region covers March to May, summer June to August, autumn September to November and winter December to February. A significant difference of maximum distributions can be observed between spring and winter in the histogram of these three areas. The sharp and narrow distribution graphs at WLG and UUM in all seasons show almost constant $\mathrm{CO}$ concentrations and are 
Fig. 4 Monthly mean CO concentrations at WLG, UUM, TAP, RYO, and MLO for 1990 2004

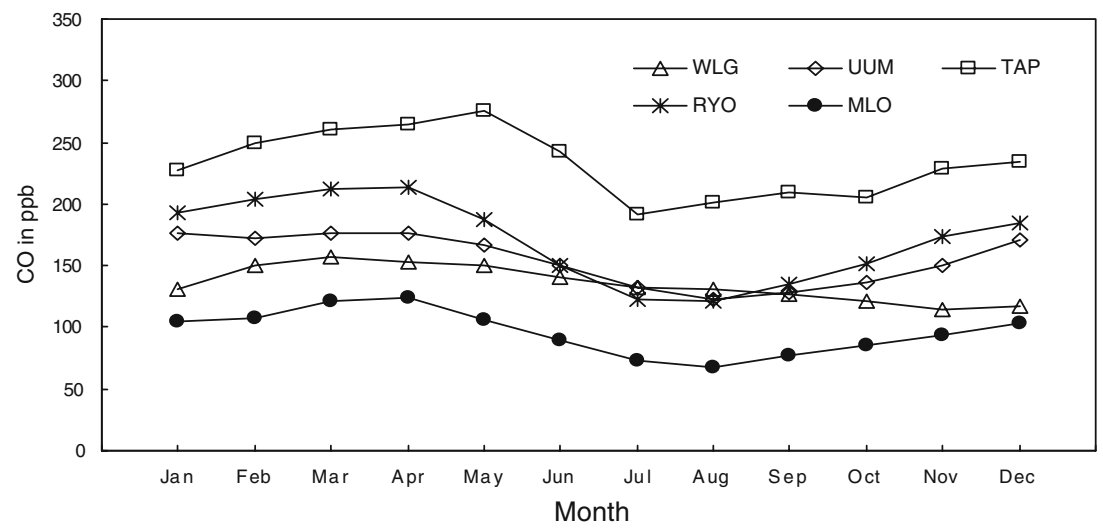

similar in summer and autumn. The wide distribution of $\mathrm{CO}$ concentrations at TAP, however, reflects the large-scale air pollution. Many cases of high and low concentration were also observed at TAP in summer compared with other seasons.
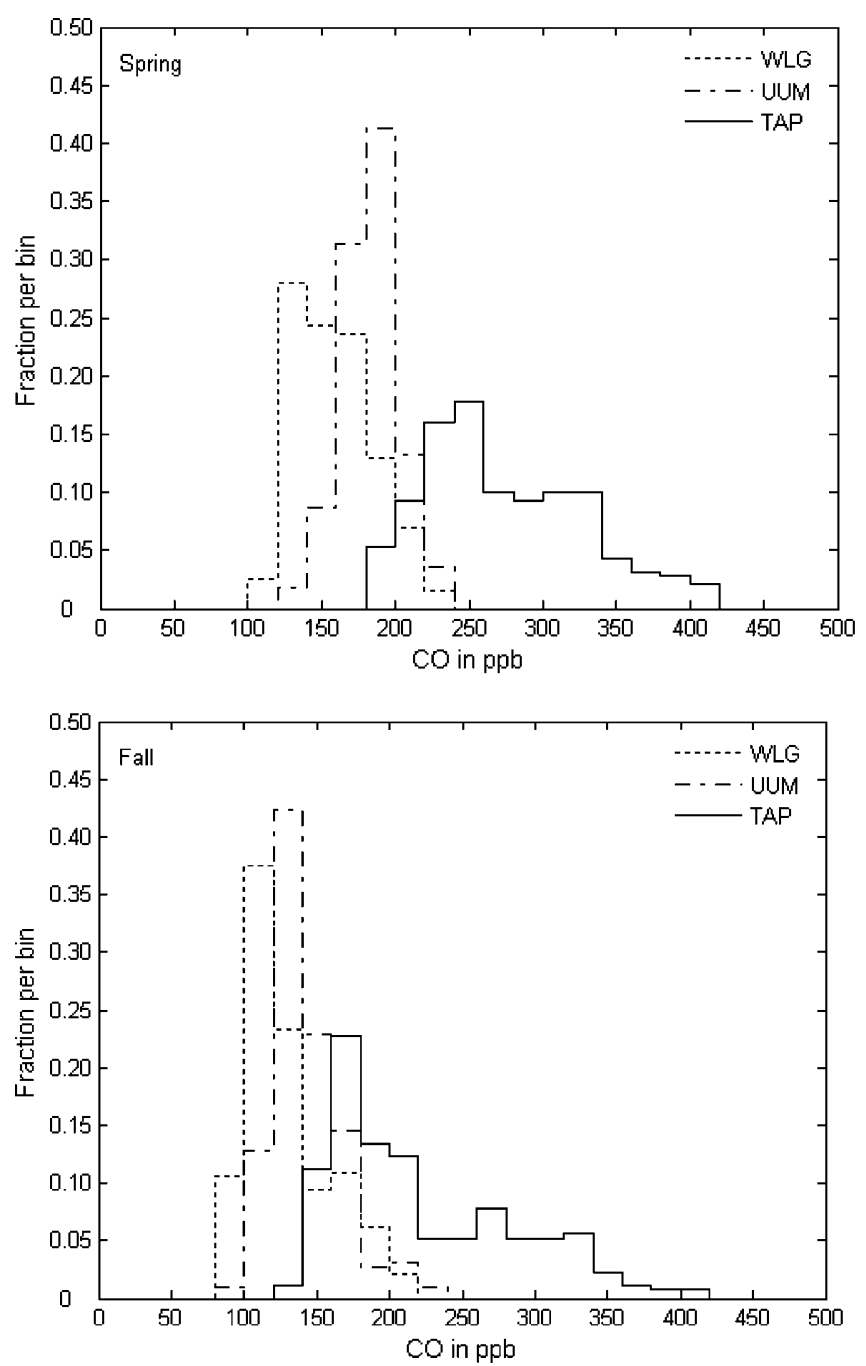

CO concentration levels according to trajectory categorisation

The cases with clear transport passages according to their origin and transport routes, originating approximately
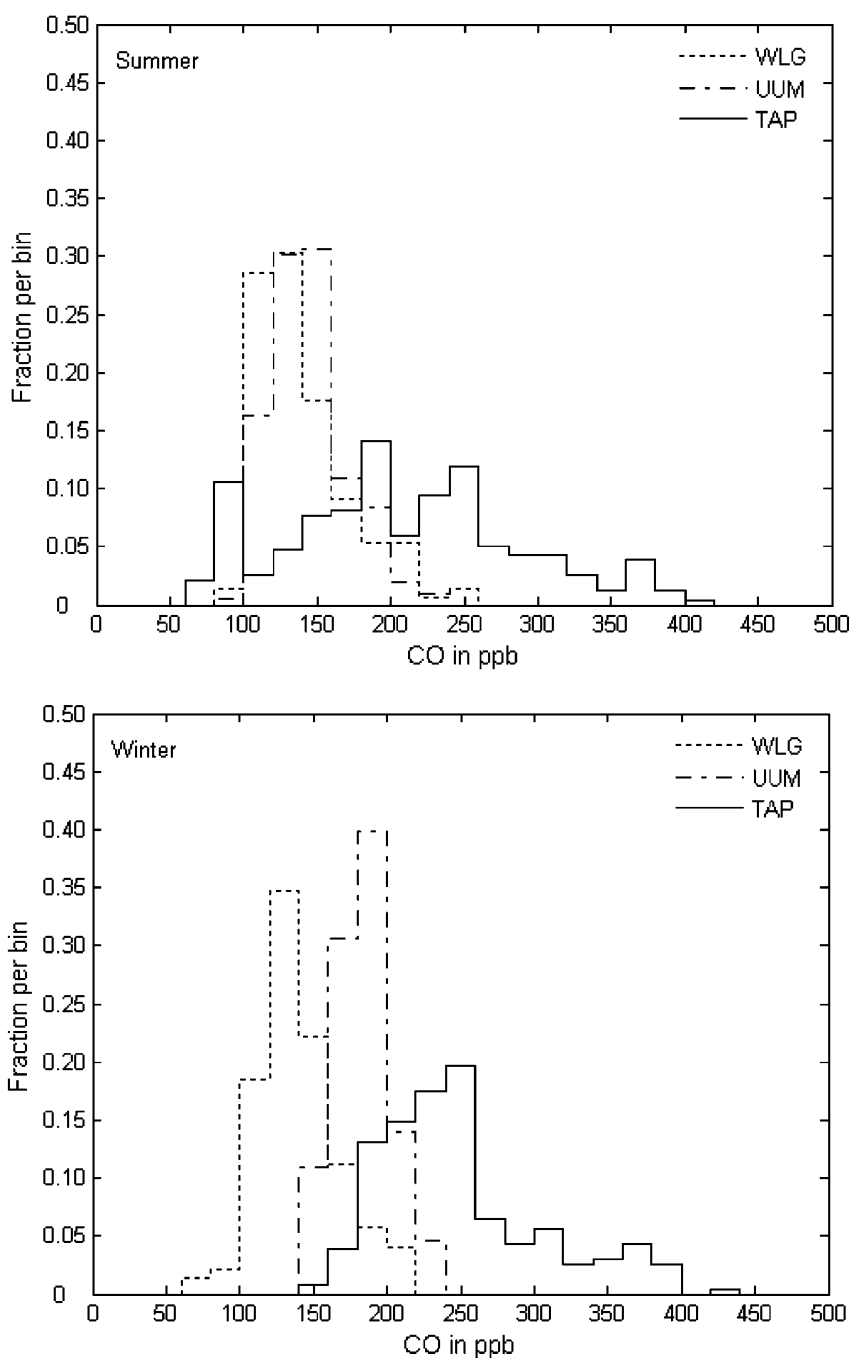

Fig. 5 Histograms of CO concentrations measured at TAP, UUM, and WLG for 1990 2004: Spring, summer, autumn and winter are MarchMay, June-August, September-November, and December-February, respectively 
1,000 km from TAP, were 242 of 526 days, classified by four categories. Representative cases of each category are shown in Fig. 6. The backward trajectory that originated in Siberia arrived from the NW NNE at the Korean Peninsula, moving past the eastern part of Inner Mongolia and Manchuria at a high altitude of more than $1.5 \mathrm{~km}$. Such $\mathrm{CBG}$ is high in frequency from the NNW NW at $68 \%$. RPC reaches TAP from the Siberian continent by way of Mongolia, the inland and eastern parts of China and the Yellow Sea, showing $19 \%$. The trajectories originating in the North Pacific move at low altitudes below $1 \mathrm{~km} ; 11 \%$ of the OBG reaching TAP by way of the East China Sea and the Yellow Sea does not pass through the emission-producing areas and $2 \%$ of PPO passes through Korea and Japan.

Table 2 shows the CO concentration levels at TAP according to categories of isentropic backward trajectories. The concentrations of $\mathrm{CO}$ by trajectory that originates on the East Asian continent reaching TAP are higher for the RPC sector (316 $\pm 56 \mathrm{ppb})$ than for CBG $(216 \pm 47 \mathrm{ppb})$, and the seasonal variation is higher for RPC than for CBG through all seasons. Concentrations of $\mathrm{CO}$ for RPC are highest in spring, which is similar to the seasonal variation in Fig. 4. The passage of trajectories that originate in the North Pacific and arrive at TAP is measured mainly in summer and partially in autumn. The weighted average of the non-RPC sectors is $200 \mathrm{ppb}$, so that the RPC sector average is $115 \mathrm{ppb}$ higher. If the $\mathrm{CO}$ emissions in China had increased in proportion to its energy consumption, we would have expected the average $\mathrm{CO}$ concentration in the

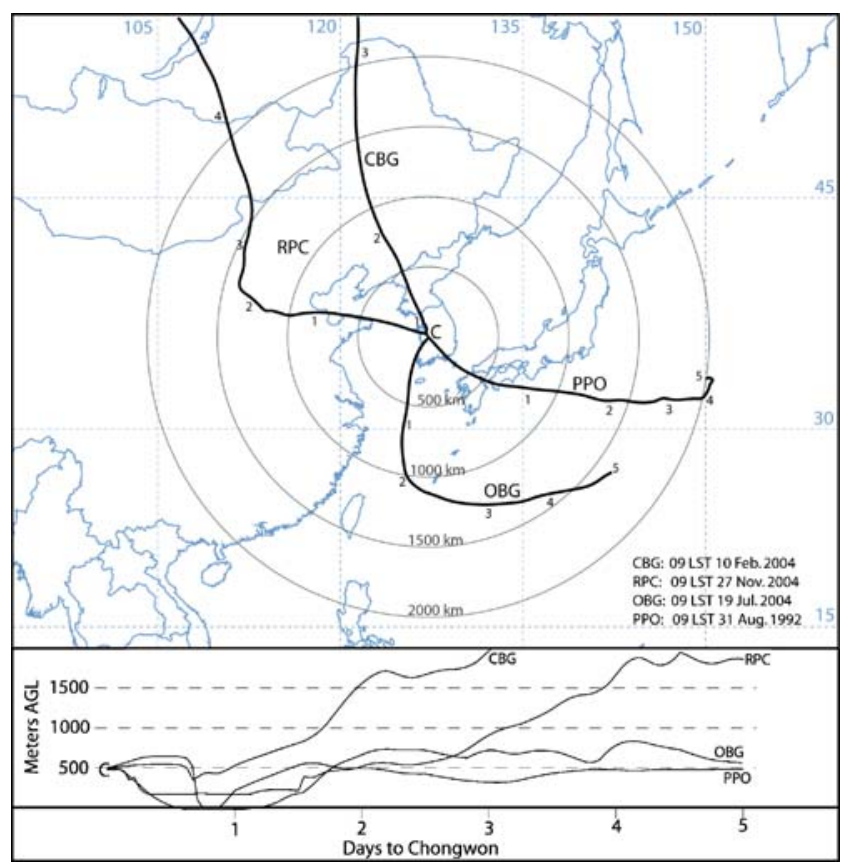

Fig. 6 Four examples of airflows arriving at TAP show the isentropic backward trajectories: $\mathrm{CBG}$ transport, RPC transport, $\mathrm{OBG}$ transport and PPO transport
Table 2 Average CO concentrations of CBG, RPC, OBG and PPO, (unit: ppb)

\begin{tabular}{lllll}
\hline Month & CBG & RPC & OBG & PPO \\
\hline Mar May & $236 \pm 41$ & $327 \pm 44$ & - & - \\
Jun Aug & - & - & $101 \pm 35$ & $161 \pm 6$ \\
Sep Nov & $193 \pm 50$ & $300 \pm 80$ & $187 \pm 3$ & - \\
Dec Feb & $223 \pm 42$ & $315 \pm 42$ & - & - \\
Average & $216 \pm 47$ & $316 \pm 56$ & $108 \pm 41$ & $161 \pm 6$ \\
\hline
\end{tabular}

RPC sector to increase from about $275 \mathrm{ppb}$ (75 above 200) to $350 \mathrm{ppb}$ (150 above 200). We see no evidence of that, which suggests that $\mathrm{CO}$ emissions as a fraction of total combustion have decreased significantly.

OBGs passing over the ocean through the East China Sea and the Yellow Sea have lower concentrations of CO $(108 \pm 41 \mathrm{ppb})$ than PPO (161 $\pm 6 \mathrm{ppb})$, which passes through Japan or Korea. The concentrations of $\mathrm{CO}$ in oceanic airflows are lower than those of continental origin because the North Pacific air masses contain low levels of $\mathrm{CO}$. $\mathrm{CO}$ reacts with $\mathrm{OH}$, which removes it from the atmosphere, and concentrations of $\mathrm{CO}$ in the atmosphere can be partly affected by the seasonal variation of $\mathrm{OH}$ (Novelli et al. 1998). The CO concentrations in East Asia, however, are more strongly affected by the spatial distribution of emissions, long-range transport and variations in emission rates.

Large-scale transport of air pollution in the Yellow Sea region

Figure 7 analyses NOAA satellite images and meteorological maps and employs the Goddard Earth Observing System (GEOS)-Chem model (Bey et al. 2001) to examine individual cases of LSTAP (Chung et al. 2001; Chung et al. 2003). The NOAA satellite image in Fig. 7a shows the LSTAP originating in the area near Shanghai down the Yangtze River in the southeastern part of China and expanding to the Korea East Sea by way of the Yellow Sea and the middle part of the Korean Peninsula. In the surface weather map (Fig. 7b) at 21 LST on December 9th, which is about $15 \mathrm{~h}$ earlier than the NOAA satellite image, the middle part of the Korean Peninsula, facing the cold front of the migrating cyclone from the north-west, started to be affected by the south-west airflow from southeastern China. The synoptic feature lasted until December 10th. Such a synoptic feature pattern, which transports large-scale air pollution from the Yellow Sea region, specifically from the eastern part of China to the Korean Peninsula, was also observed in a previous study (Kim and Chung 2005).

The transport of large-scale air pollution observed in the NOAA satellite image coincides with the distribution of $\mathrm{CO}$ concentration simulated at $930 \mathrm{hPa}(700 \mathrm{~m})$ by the GEOS- 
a

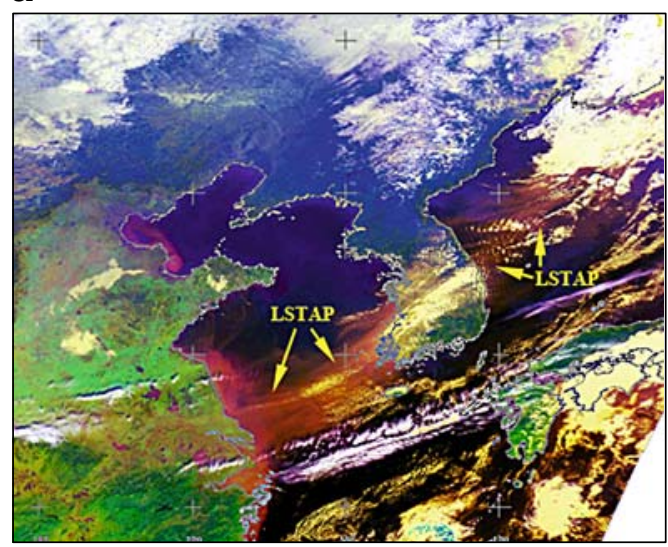

C

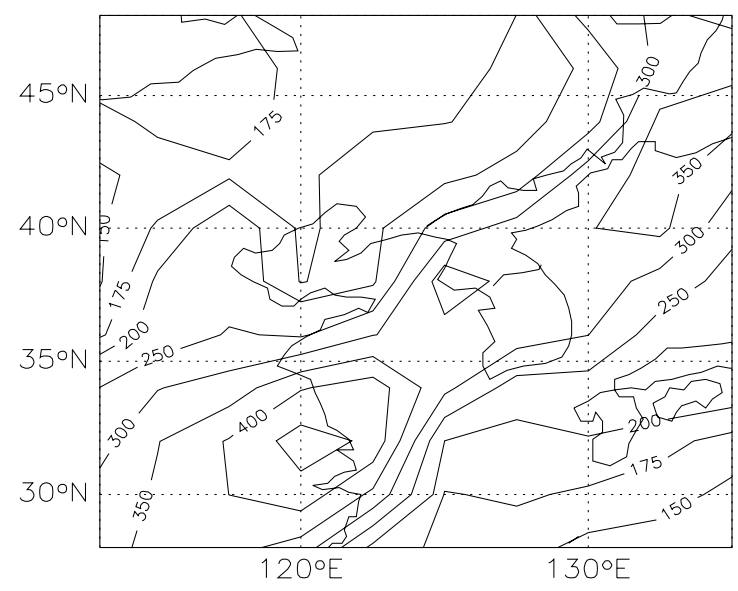

Fig. 7 a Satellite image of NOAA 17 (1141 LST, 10 Dec 2004) showing a large-scale transport of air pollution (LSTAP) over the Yellow Sea, Korea and the Korea East Sea. b A meteorological map showing the movement of airflow from south-east China to the Korea East Sea. c Model simulation of CO concentrations at $930 \mathrm{hPa}$

Chem model (Fig. 7c). At $930 \mathrm{hPa}$, the region near Shanghai shows a concentration range of over $350 \mathrm{ppb}$ and the concentration range of the region that expands to the Korea East Sea toward the north-east through the Yellow Sea and the Korean Peninsula is over $300 \mathrm{ppb}$, which is observed in the shape of a large-scale pollution mass, as shown in the NOAA satellite image. Figure $7 \mathrm{~d}$ is the meridional average of the concentration of $\mathrm{CO}$ according to altitude, in the region of $28 \sim 48^{\circ} \mathrm{N}$ latitude and $113 \sim 135^{\circ}$ E longitude, based on the GEOS-Chem model. A high concentration range of an average of over $250 \mathrm{ppb}$ was observed above the eastern part of China and the Korean Peninsula. While the intervals between the isograms become larger in altitudes over $3 \mathrm{~km}$, the isograms of 125 200 ppb CO concentration are concentrated at an altitude of $1 \sim 3 \mathrm{~km}$, which indicates the altitude distribution in LSTAP. b

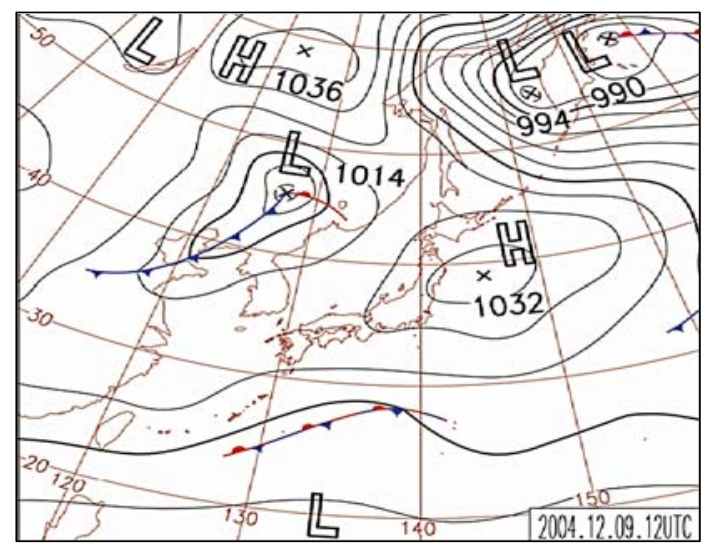

d

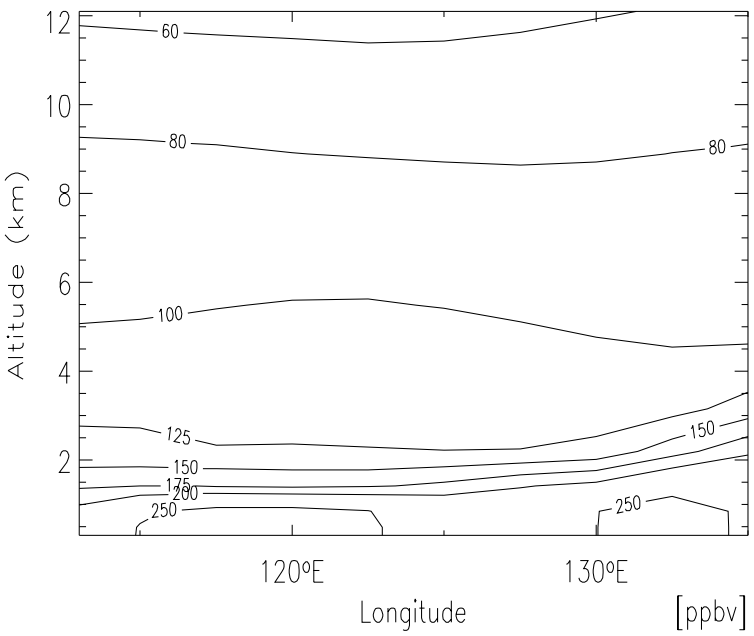

$(700 \mathrm{~m})$ and d Meridional average (latitude, 28 48N; longitude, 113 135E) of CO concentrations conducted by use of GEOS-CHEM global three-dimensional model of tropospheric chemistry (http:// www-as.harvard.edu/chemistry/trop/geos/)

\section{Conclusions}

An analysis of a long-term observation of $\mathrm{CO}$ concentration conducted at WLG in China, UUM in Mongolia, TAP in Korea and RYO in Japan between 1991 and 2004 was made to analyse the regional background concentration level of $\mathrm{CO}$ in East Asia. $\mathrm{CO}$ values in these areas are high in annual average concentrations of $\mathrm{CO}$, in the order of WLG $135 \pm 22$ ppb, UUM $155 \pm 26$ ppb, RYO $171 \pm 36 \mathrm{ppb}$ and TAP $233 \pm 41 \mathrm{ppb}$. In terms of seasonal variation of CO concentration, all the areas except WLG are high in spring and low in summer, which is similar to observations made in other areas in Japan. WLG and UUM are geographically at a similar latitude to TAP, and RYO is downwind of the East Asian continent. TAP, located 350 700 km downwind of China, is under greater influence of large-scale air pollution than the other observation sites in this study. 
The CO concentration at TAP on the Korean Peninsula can be divided into four categories according to an analysis of the isentropic backward trajectories. The concentrations of CO of CBG and RPC of East Asian origin were 216 \pm 47 and $316 \pm 56 \mathrm{ppb}$, respectively. OBG, which originates in the low-latitude North Pacific and travels above the ocean, was $108 \pm 41 \mathrm{ppb}$, and PPO, which passes through Korea or Japan, was $161 \pm 6 \mathrm{ppb}$. The concentration of $\mathrm{CO}$ in an airflow originating in high-latitude Siberia and affecting TAP is higher than that of the passage from the low-latitude North Pacific. In the East Asian region, the case analysis using the NOAA satellite image proves that TAP is being affected by the large-scale transport of air pollution from China.

Acknowledgments The authors wish to thank the Korea Meteorological Administration (CATER 2006-3103) for providing science subvention. In addition, data provided by J.M. Harris, T.J. Conway and by Japan Meteorological Agency are appreciated.

\section{References}

Akimoto $\mathrm{H}$, Mukai $\mathrm{H}$, Nishikawa M, Murano K, Hatakeyama S, Liu CM, Buhr M, Hsu KJ, Jaffe DA, Zhang L, Honrath R, Merrill JT, Newell RE (1996) Long-range transport of ozone in the East Asian Pacific rim region. J Geophys Res 101:1999-2010

Bey I, Jacob DJ, Yantosca RM, Logan JA, Field BD, Fiore AM, Li Q, Liu HY, Mickley LJ, Schultz MG (2001) Global modeling of tropospheric chemistry with assimilated meteorology: model description and evaluation. J Geophys Res 106:23073-23096

Chung YS, Lee KJ (1992) On the regional background levels of $\mathrm{CH}_{4}$ observed at Tae-ahn Peninsula in Korea during 1990-1992. Journal of Korea Air Pollution Research Association 1(2):33-48

Chung YS, Lee KJ (1993) On the regional background level of CO observed at Tae-ahn Peninsula in Korea during 1990-1992. Journal of Korea Air Pollution Research Association 9(3):200-206

Chung YS, Kim HS, Park KH (2001) Acidic precipitation and largescale transport of air pollutants observed in Korea. Water, Air, and Soil Pollution 130:367-372

Chung YS, Kim HS, Kim YS (2003) On large-scale air pollution in the Yellow Sea region: satellite and ground measurements. Journal of Korean Society for Atmospheric Environment 19:83-88

Draxler RR, Rolph GD (2003) HYSPLIT (HYbrid Single-Particle Lagrangian Integrated Trajectory) Model access via NOAA ARL READY. http://www.arl.noaa.gov/ready/hysplit4.html. NOAA Air Resources Laboratory, Silver Spring, MD

Hoell JM, Davis DD, Liu SC, Newell R, Shipham M, Akimoto H, McNeal RJ, Bendura RJ, Drewry JW (1996) Pacific Exploratory
Mission-West A (PEM-West A): September-October 1991. J Geophys Res 101:1641-1653

Hoell JM, Davis DD, Liu SC, Newell RE, Akimoto H, McNeal RJ, Bendura RJ (1997) The Pacific Exploratory Mission-West Phase B: February-March 1994. J Geophys Res 102:28223-28239

Huebert B, Bates T, Russell P, Seinfeld J, Wang M, Uematsu M, Kim YJ (2003) An overview of ACE-Asia: strategies for quantifying the relationships between Asian aerosols and their climatic impacts. J Geophys Res 108:8633

Jacob DJ, Crawford JH, Kleb MM, Connors VS, Bendura RJ, Raper JL, Sachse GW, Gille JC, Emmons L, Heald CL (2003) The Transport and Chemical Evolution over the Pacific (TRACE-P) aircraft mission: design, execution, and first results. J Geophys Res 108:9000

Jaffe D, Mahura A, Kelley J, Atkins J, Novelli PC, Merrill J (1997) Impact of Asian emissions on the remote North Pacific atmosphere: interpretation of CO data from Shemya, Guam, Midway and Mauna Loa. J Geophys Res 102(D23):28627-28635

Kato S, Pochanart P, Hirokawa J, Kajii Y, Akimoto H, Ozaki Y, Obi K, Katsuno T, Streets DG, Minko NP (2002) The influence of Siberian forest fires on carbon monoxide concentrations at Happo, Japan. Atmos Environ 36:385-390

Kim HS, Chung YS (2003) Surface ozone and precursors observed in a rural area of Korea 1993-2001. Journal of the Korean Meteorological Society 39(6):689-698

Kim HS, Chung YS (2005) On surface $\mathrm{O}_{3}$ associated with long-range transport in the Yellow Sea region. Water, Air, and Soil Pollution 165:95-112

Lee KJ, Chung YS (1993) On the background levels of CO2 observed at Tae-ahn Peninsula in Korea during 1990-1992. Journal of Korea Air Pollution Research Association 9(1):61-68

Liang Q, Jaegle L, Jaffe DA, Weiss-Penzias P, Heckman A, Snow JA (2004) Long-range transport of Asian pollution to the northeast Pacific: seasonal variations and transport pathways of carbon monoxide.. J Geophys Res 109:D23S07

Logan JA, Prather MJ, Wofsy SC, McElroy MB (1981) Tropospheric chemistry: a global perspective. J Geophys Res 86:7210-7254

Novelli PC, Masarie KA, Lang PM (1998) Distributions and recent changes of carbon monoxide in the lower troposphere. J Geophys Res 103(D15):19015-19033

Pochanart P, Hirokawa J, Kajii Y, Akimoto H, Nakao M (1999) Influence of regional-scale anthropogenic activity in northeast Asia on seasonal variations of surface ozone and carbon monoxide observed at Oki Japan. J Geophys Res 104:3621-3631

Pochanart P, Kato S, Katsuno T, Akimoto H (2004) Eurasian continental background and regionally polluted levels of ozone and $\mathrm{CO}$ observed in northeast Asia. Atmos Environ 38:13251336

Streets DG, Tsai NY, Akimoto H, Oka K (2001) Trends in emissions of acidifying species in Asia, 1987-1997. Water, Air, and Soil Pollution 130:187-192

Streets DG, Bond TC, Carmichael GR, Femandes SD, Fu Q, He D, Klimont Z, Nelson SM, Tsai NY, Wang MQ, Woo JH, Yarber KF (2003) An inventory of gaseous and primary aerosol emissions in Asia in the year 2000. J Geophys Res 108(D21):8809 